\title{
Cikkismertetés: Az észak-karolinai Egészséges Élelmiszer-kiskereskedelmi Program étrendi hatásai az "élelmiszersivatagokban" élökre
}

\author{
Article review: The dietary impact of the North Carolina Healthy Food Small \\ Retailer Program on people live in food deserts
}

\begin{tabular}{ll}
\hline Ismertető: & Patay Panna Réka \\
Ismertetett cikk: & Jilcott Pitts, S. B., Wu, Q., Truesdale, K. P., et al. (2021). A four-year observational study \\
& to examine the dietary impact of the North Carolina Healthy Food Small Retailer \\
& Program, 2017-2020. International Journal of Behavioral Nutrition and Physica \\
& Activity, 18(44) https://doi.org/10.1186/s12966-021-01109-8 \\
Kulcsszavak: & $\begin{array}{l}\text { egészséges kiskereskedés; élelmiszerkörnyezet; egészségügyi politika; élelmiszer- } \\
\text { sivatag, gyümölcsök és zöldségek } \\
\text { Keywords: }\end{array}$ \\
& healthy corner stores; food environment; health policy; food desert; fruits and \\
& vegetables
\end{tabular}

Beküldve: 2021. 07. 02., doi: $\underline{10.24365 / \text { ef.v62i3.6747 }}$

\section{HÁTTÉR}

Az észak-karolinai Egészséges Élelmiszerkiskereskedelmi Programot (Healthy Food Small Retailer Program, továbbiakban, HFSRP) 250000 dolláros éves költségvetéssel iktatták törvénybe, amely legfeljebb 25000 dollár támogatást biztosított a kritériumoknak megfelelő kisboltok részére egészséges ételek és italok (továbbiakban egészséges élelmiszerek) tárolására alkalmas eszközbeszerzésre. A bemutatott cikk egy olyan megfigyeléses természetes kísérletet ismertet, amely dokumentálja a HFSRP hatását a boltok élelmiszerkínálatára, illetve a vevők vásárlási szokásaira és étrendjére.

\section{MÓDSZER}

A szerzők megvizsgálták a HFSRP-ben részt vevő és a kontroll boltok közötti különbségeket keresztmetszeti, a kisboltokban vásárlók által alkotott mintákból, bolti megfigyelések és helyszíni felmérések (1 261 vásárló, 22 boltban, 20172020 között, 499 vásárló a HFSRP boltban és 762 vásárló a kontroll boltokban) összevetésével, az alábbiakra való tekintettel: 1) az egészséges élelmiszerek bolti elérhetősége, minősége és ára, 2) "táska-ellenőrzés”: a vásárolt ételek és italok egészségessége és 3) a vásárlók önbevalláson alapuló és objektíven (Veggie Meter ${ }^{\circledR}{ }^{i}$-rel) mért étkezési szokásainak változása. Az észlelt különbségeket (HFSRP vs. kontroll boltok) a bolt Egészséges Élelmiszer Ellátottsága (Health Food Supply) és az Egészséges Étkezés Index-2010 (Healthy Eating Index-2010) pontszám tekintetében ismételt varianciaanalízissel értékelték. $\mathrm{Az}$ intervenció étrendre gyakorolt hatását „különbségek különbsége” módszerrel mérték, beleértve a becsült részvételi valószínűséget is.

\section{EREDMÉNYEK}

Javulás volt tapasztalható az egészséges élelmiszerek boltszintű kínálatában a program indulása utáni első 12 hónapban a HFSRP-ban részt vevő boltok esetében, míg a kontroll boltokban nem. A programban részt vevő boltokban 2017 és 2019 között nőtt az egészséges élelmiszerek elérhetőségét, minőségét és árát értékelő pontszám, míg a kontrollboltokban csökkent. Az

\footnotetext{
i Jilcott Pitts, S., Jahns, L., Wu, Q., Moran, N., Bell, R., Truesdale, K., \& Laska, M. (2018). A non-invasive assessment of skin carotenoid status through reflection spectroscopy is a feasible, reliable and potentially valid measure of fruit and vegetable consumption in a diverse community sample. Public Health Nutrition, 21(9), 1664-1670. doi:10.1017/S136898001700430X
} 
önbevalláson alapuló gyümölcs- és zöldségfogyasztás (adag/nap) a statisztikai szignifikancia határán változott, de a várthoz képest ellenkező irányba, azaz a kontroll boltokban nagyobb mértékben nőtt, mint a programban részt vevő boltok vásárlóinál. A Veggie Meter ${ }^{\circledR}$-rel mért gyümölcs- és zöldségfogyasztásban nem volt szignifikáns különbség a programban részt vevő és a kontroll boltokban vásárlók között.

A HFSRP tartósan nem javított a vásárlási és étkezési szokásokon, ennek oka lehet a program időtartama; a részt vevő boltok vártnál kisebb száma; az egészséges élelmiszerek beszerzésének és tárolásának nehézsége a kereskedések számára; valamint a fogyasztók oktatásának és tájékoztatásának elmaradása. A tanulmány erőssége, hogy nagy és változatos mintát használt és objektív mérésekkel is vizsgálta a fogyasztók vásárlását, illetve a gyümölcs- és zöldségfogyasztását az önbevalláson kívül. Vizsgálta az élelmiszersivatagokii lakosságának viselkedését is, ugyanakkor gyengesége, hogy a vizsgált csoportok eltértek összetételben és viselkedésben is.

\section{KÖVETKEZTETÉSEK}

Bár a HFSRP jó lépéseket tesz az egészséges élelmiszerek elérhetőségéért a rosszul ellátott területeken, egyéb faktorokra nem kínált megoldást: a vásárlók oktatása, az árazás ösztönzése, hirdetés, elhelyezés és az egészségesebb élelmiszerek elosztása a kisboltokban. A program jövőbeli ismétlése esetén több figyelmet kell fordítani a tágabb összefüggésekre és a bizonyítékokon alapuló megközelítésekre, hogy népszerűsítsék az egészségesebb élelmiszerek fogyasztását, beleértve a további technikai segítséget a kiskereskedőknek és a vásárlók ösztönzését. Maga a program alulfinanszírozott volt a végrehajtó és az értékelő személyzet tekintetében. Ezek mellett a pénzügyileg nyereséges modellek és ellátási láncok megalkotása is kritikus a hasonló kezdeményezések sikerének szempontjából.

\section{TANULSÁGOK A HAZAI SZAKEMBEREK SZÁMÁRA}

Hazánkban is vizsgálandó lehet a kistérségek, leszakadó térségek kisboltjainak választéka, az általuk forgalmazott egészséges élelmiszerek köre és annak bővítési lehetőségei, de fontos tanulság az HFSR program eredményeiből, hogy nem elég csupán a kisboltok technológiai fejlesztésére összpontosítani. Komplex szemléletmód nélkül, amely a teljesség igénye nélkül magába foglalja a fenntarthatóságot is figyelembe vevő beszerzést, a megfelelő árazási modellt és ellátási láncot, illetve a fogyasztók oktatását és ösztönzését is, kétséges az effajta kezdeményezések sikere. Ezen kívül meggondolandó az élelmiszersivatagokra jellemző alacsonyabb jövedelmekhez igazított, szakemberek által kialakított egészséges élelmiszerek körének meghatározása. Vizsgálható továbbá, milyen ösztönző módszerekkel lehet élelmiszer-nagykereskedéseket, áruházláncokat támogatni az élelmiszersivatagok jobb ellátása érdekében.

\section{HIVATKOZÁSOK}

Dutko, P., Ver Ploeg, M., Farrigan, T. (2012). Characteristics and Influential Factors of Food Deserts. Economic Research Report Number 140. https://www.ers.usda.gov/webdocs/publications/45014/30940_err140.pdf

Információk a szerzőről:

Patay Panna Réka, dietetikus, patay.panna@gmail.com

\footnotetext{
ii Az Amerikai Egyesült Államok Mezőgazdasági Minisztériuma (United States Department of Agriculture) szerint élelmiszersivatagnak tekinthetők azok a területek, ahol a lakosságnak korlátozott hozzáférése van az egészséges, megfizethető árú élelmiszerhez. Ezeken a területeken jellemző az alacsonyabb jövedelmű népesség, illetve kevesebb és kisebb, a lakosság jelentős részétôl nagy távolságra található élelmiszer-kiskereskedés (Dutko, Ver Ploeg és Farrigan, 2012).
} 